\title{
NEMZETKÖZI HEGESZTŐ SZAKEMBEREK KÉPZÉSI RENDSZERE
}

\section{EDUCATION SYSTEM OF INTERNATIONAL WELDING PROFESSIONALS}

\author{
Bagyinszki Gyula ${ }^{1}$, Bitay Enikö ${ }^{2}$ \\ ${ }^{1}$ Óbudai Egyetem, Bánki Donát Gépész és Biztonságtechnikai Mérnöki Kar, \\ Magyarország, 1081 Budapest, Népszinház u. 8, bagyinszki.gyula@bgk.uni- \\ obuda.hu \\ ${ }^{2}$ Sapientia - Erdélyi Magyar Tudományegyetem, Müszaki és Humántudományok \\ Kar, Románia, 540485 Marosvásárhely (Koronka), Segesvári út 1.C., \\ ebitay@ms.sapientia.ro
}

\begin{abstract}
The welding is a priority industrial technology, which is responsible for coordinating professionals education and examination of all the EWF, all the member countries of IIW is conducted under the unified directive. This article organizes the knowledge in regard of information providing about the opportunities, or providing support for individual training levels to select one.
\end{abstract}

Keywords: welding, engineer, technologist, specialist, practitioner

\section{Összefoglalás}

A hegesztés kiemelt fontosságú ipari technológia, melynek koordinációjáért felelős szakemberek képzése és vizsgáztatása mind az EWF, mind az IIW tagországokban egységes irányelv szerint folyik. Ez a cikk az ezzel kapcsolatos információkat rendszerezi, tájékoztatást adva a lehetőségekről, avagy segítséget nyújtva az egyes képzési szintek közüli választásban.

Kulcsszavak: hegesztö, mérnök, technológus, specialista, kiemelt hegesztö

\section{A képzések kerete}

1993-tól lépett érvénybe az EWF (European Federation for Welding, Joining and Cutting; Európai Hegesztési, Kötési és Vágási Szövetség) Irányelve az Európai Hegesztőmérnökök (EWE = European Welding Engineer), Hegesztőtechnológusok (EWT $=$ European Welding Technologist), Hegesztőspecialisták (EWS = European Welding Specialist), Kiemelt Hegesztők $($ EWP $=$ European Welding Practitioner) oktatására és képesítésére vonatkozó minimális követelményekről. A nemzeti hegesztési szervezetek - mint EWF tagok kölcsönösen elismerték az Irányelvnek megfelelő vizsgán alapuló, bármely tagállam által kibocsátott EWE, EWT, EWS, EWP diplomát. Az IIW (International Institute of Welding, Nemzetközi Hegesztési Intézet) ezt az Irányelvet a Nemzetközi Hegesztőmérnök (IWE = International Welding Engineer), Hegesztőtechnológus (IWT = International Welding Technologist), Hegesztőspecialista (IWS = International Welding Specialist), Kiemelt Hegesztő (IWP = International 
Welding Practitioner) képzés Irányelveként fogadta el 1997-töl. Azóta ezen Irányelv szerint folyik a képzés és a képesítés mind az EWF, mind az IIW tagországokban. A képzésben résztvevők az eredményes vizsgák után IWE, IWT, IWS, IWP diplomát kapnak, melynek alapján EWE, EWT, EWS, EWP diploma is kiállítható részükre. A hegesztés koordinációját ellátó szakszemélyzet képzésére, vizsgáztatására, minősítésére vonatkozó Irányelv felülvizsgálatát és fejlesztését az IIW végzi, jelenleg az [1] szerinti változat vagy érvényben.

\section{A képzések feltételei}

$\mathrm{Az}$ egyenértéküség érdekében az Irányelv minimálisan teljesítendő követelményeket - moduláris tantervet és tananyagot, illetve ezekhez differenciáltan meghatározott óraszámot (1. ábra) - ír elő. Az Irányelv szerinti képzésekben (2. ábra) való részvétel feltételei:

-az elöírt szintü szakmai (iskolai) végzettséget igazoló oklevél vagy bizonyítvány bemutatása;

\begin{tabular}{|c|c|c|c|c|c|c|c|c|}
\hline \multirow{2}{*}{$\begin{array}{c}\text { Elméleti képzés } \\
\text { (1. Rész és. Rész) } \\
\text { moduljai }\end{array}$} & \multicolumn{9}{|c|}{ tanítási órák száma } \\
\cline { 2 - 9 } & \multicolumn{2}{|c|}{ IWE } & \multicolumn{2}{|c|}{ IWT } & \multicolumn{2}{c|}{ IWS } & \multicolumn{2}{c|}{ IWP } \\
\cline { 2 - 9 } & $1 R+3 R$ & $1 R$ & $1 R+3 R$ & $1 R$ & $1 R+3 R$ & $1 R$ & $1 R+3 R$ & $1 R$ \\
\hline 1. Hegesztési eljárások és berendezések & 90 & 35 & 81 & 35 & 48 & 13 & 29 & 13 \\
\hline 2. Anyagok és viselkedésük a hegesztés során & 115 & 39 & 96 & 37 & 56 & 19 & 23 & 12 \\
\hline 3. Méretezés és tervezés & 62 & 14 & 44 & 13 & 24 & 4 & 6 & 0 \\
\hline 4. Gyártás, mérnöki alkalmazások & 114 & 0 & 81 & 0 & 54 & 0 & 28 & 0 \\
\hline Összes elméleti óraszám & 381 & 88 & 302 & 85 & 182 & 36 & 86 & 25 \\
\hline Gyakorlati képzés (2. Rész) & 60 & - & 60 & - & 60 & - & 60 & - \\
\hline Összes óraszám & 441 & - & 362 & - & 242 & - & 146 & - \\
\hline
\end{tabular}

1. ábra. Az Irányelv szerinti nemzetközi hegesztő szakember képzések óraszámai

\section{International Welding Engineer (Nemzetközi HegesztöMérnök)}

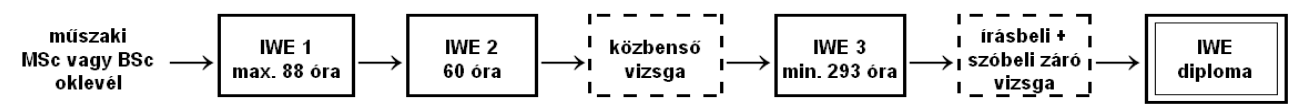

International Welding Technologist (Nemzetközi HegesztóTechnológus)

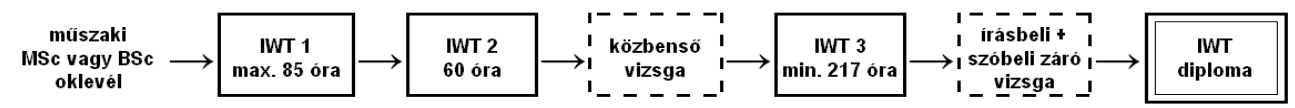

International Welding Specialist (Nemzetközi HegesztöSpecialista)

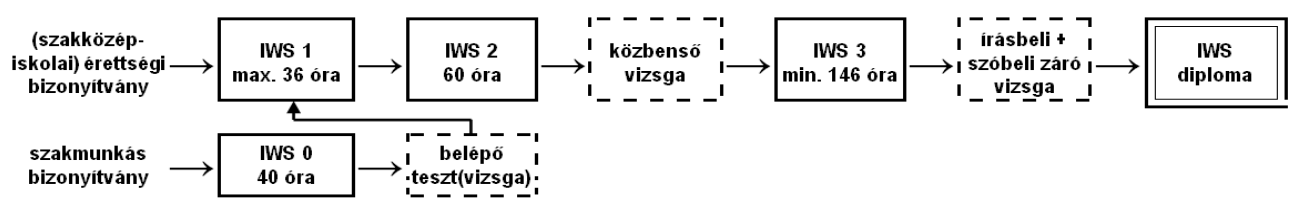

International Welding Practitioner (Nemzetközi Kiemelt Hegesztő)

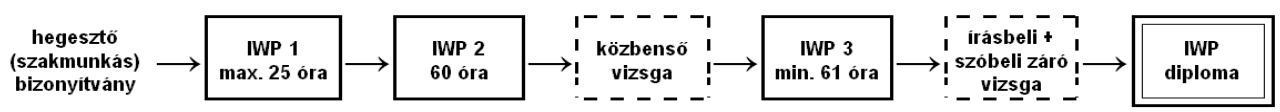

2. ábra. Az Irányelv szerinti nemzetközi hegesztő szakember képzések szakaszai 


\begin{tabular}{|c|c|}
\hline $\begin{array}{l}\text { 0.1. Méréstechnikai alapok hegesztési alkalmazásokkal } \\
\text { 0.2. Müszaki szamitäsok } \\
\text { 0.3. Müszaki rajzok } \\
\text { 0.4. Elektrotechnikai alapok } \\
\text { 0.5. Kémiai alapok } \\
\text { 0.6. Anyagismereti alapok } \\
\text { 0.7. Fémtermékek } \\
\text { 0.8. Anyagok megmunkálása } \\
\text { 0.9. Müszaki mechanika } \\
\text { 0.10. Kötöelemek } \\
0.11 \text {. Szilárdság(tan)i számitások }\end{array}$ & $\begin{array}{l}60 \text { órás gyakorlati képzés (IWE, IWT, IWS) } \\
\text { - Gázhegesztés és lángvágás } \\
\text { - Bevont elektródás kézi ívhegesztés } \\
\text { - TIG-hegesztés } \\
\text { - MIG/MAG-hegesztés + porbeles elektródás ívheg. } \\
\text { - gyökfaragás } \\
\text { - keményforrasztás } \\
\text { - plazmahegesztés, plazmavágás } \\
\text { - fedett ivü hegesztés } \\
\text { - ellenálláshegesztés, dörzshegesztés } \\
\text { - elektronsugaras hegesztés, lézerhegesztés } \\
\text { - egyéb hegesztési eljárāsok }\end{array}$ \\
\hline 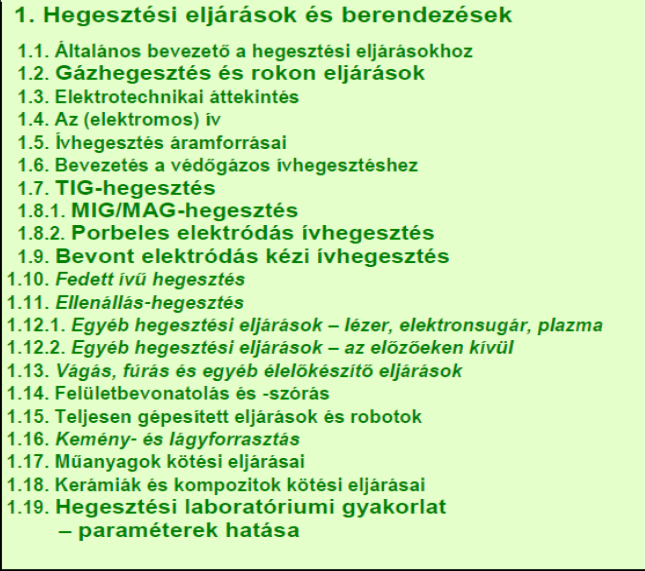 & $\begin{array}{l}\text { 2. Anyagok és viselkedésük a hegesztés során } \\
\text { 2.1. Fémek szerkezete és tulajdonságai } \\
\text { 2.2. Fázisdiagramok és ötvözetek } \\
\text { 2.3. Vas-karbon ötvözetek } \\
\text { 2.4. Acélok gyártása és osztályozása } \\
\text { 2.5. Szerkezeti acélok viselkedése ömlesztö hegesztéskor } \\
\text { 2.6. Repedés jelensége hegesztett kötésekben } \\
\text { 2.7. Törés és a törések különbözö típusai } \\
\text { 2.8. Alapanyagok és hegesztett kötések hökezelése } \\
\text { 2.9. Ötvözetlen szerkezeti acélok } \\
\text { 2.10. Nagyszilárdságú acélok } \\
\text { 2.11. Szerkezeti és nagyszilárdságú acélok alkalmazásai } \\
\text { 2.12. Kúszás és kúszásálló acélok } \\
\text { 2.13. Acélok nagyon kis hömérsékletũ (kriogén) alkalmazásokra } \\
\text { 2.14. Bevezetés a korroziohoz } \\
\text { 2.15. Korrózió- és höálló acélok } \\
\text { 2.16. Bevezetés a kopáshoz és a védörétegekhez } \\
\text { 2.17. Öntöttvasak és acélöntvények } \\
\text { 2.18. Réz és rézötvözetek } \\
\text { 2.19. Nikkel és nikkelötvözetek } \\
\text { 2.20. Alumínium és alumíniumötvözetek } \\
\text { 2.21. Titán és egyéb fémek (Mg, Ta, Zr), ill. ötvözeteik } \\
\text { 2.22. Különbözó anyagok kötése } \\
\text { 2.23. Anyagok és hegesztett kötések roncsolásos vizs. }\end{array}$ \\
\hline $\begin{array}{l}\text { 3. Méretezés és tervezés } \\
\text { 3.1. Szerkezetek tervezésének (mechanikai) alapelvei } \\
\text { 3.2. Anyagok szilárdság(tan)ának alapjai } \\
\text { 3.3. Hegesztett és forrasztott kötés tervezése } \\
\text { 3.4. Hegesztett kötés méretezésének alapjai } \\
\text { 3.5. Hegesztett szerkezetek viselkedése különbözô terhelések alatt } \\
\text { 3.6. Hegesztett szerkezetek tervezése jellemzöen statikus terhelésre } \\
\text { 3.7. Hegesztett szerkezetek viselkedése ciklikus terhelés alatt } \\
\text { 3.8. Ciklikusan terhelt hegesztett szerkezetek tervezése } \\
\text { 3.9. Nyomástartó berendezések tervezése } \\
\text { 3.10. Alumínium ötvözetekböl készült szerkezetek tervezése } \\
\text { 3.11. Bevezetés a törésmechanikába }\end{array}$ & $\begin{array}{l}\text { 4. Gyártás, mérnöki alkalmazások } \\
\text { 4.1. Bevezetés a hegesztett szerkezetgyártás mínōségügyébe } \\
\text { 4.2. Minőségirányítás a gyártás során } \\
\text { 4.3. Maradó feszültségek és deformációk } \\
\text { 4.4. Gyártóeszközök, hegesztökészülékek, tájoló elemek } \\
\text { 4.5. Egészség és biztonság } \\
\text { 4.6. Mérés, szabályozás, adatrögzítés hegesztéskor } \\
\text { 4.7. Eltérések és elfogadási kritériumok } \\
\text { 4.8. Roncsolásmentes vizsgálatok } \\
\text { 4.9. Gazdaságtan és termelékenység } \\
\text { 4.10. Javítóhegesztés } \\
\text { 4.11. Betonacelok hegesztett kötései } \\
\text { 4.12. Esettanulmányok }\end{array}$ \\
\hline
\end{tabular}

Növelt betűszélességgel jelölve a gyakorlati képzést ill. laboratóriumi gyakorlatot is tartalmazó vagy azzal kiegészüló témakörök

Dölt betükkel jelölve a demonstrációt vagy videoprezentációt igénylố témakörök

3. ábra. Az Irányelv szerinti nemzetközi hegesztő szakember képzések moduljai és témakörei

- legalább

$$
2 \ldots 4
$$

meghatározott) éves

(képzésenként rokon (fémipari) területen szerzett szakirányú gyakorlat igazolása;

-20 éves életkor betöltése (a nem diplomás bemeneti feltételü képzéseknél);

- egészségügyi alkalmasság igazolása;

- valamint az IWS képzésnél legalább $2 \mathrm{db}$ érvényes MSZ EN 287/MSZ EN ISO 9606 szabvány szerinti hegesztőminősítés; az IWP képzésnél megfelelő darabszámú MSZ EN 287/ISO 9606 szabvány szerinti - H-L045 ss nb, vagy ASME IX 6G, vagy MSZ EN 287/ISO 9606 szerinti PE ss nb, vagy PC és PF ss $\mathrm{nb}$ - érvényes minősítés.

A képzések szakmai felügyeletét az ANB (Authorised National Body, Meghatalmazott Nemzeti Testület) Magyarországon a Magyar Hegesztéstechnikai és Anyagvizsgálati Egyesülés (MHtE) - látja el. Képzés szervezésére és lebonyolítására az ANB által erre akkreditált oktató- és képesítési hely (ATB 
$=$ Authorised Training Body) jogosult. Az egyes oktató- és képzőhelyek a különböző modulok szerinti csoportosításnak megfelelöen szervezik a tantárgyi témakörök (3. ábra) oktatását.

\section{A képzések követelményei}

Az egyes képzési szintek legfontosabb követelményeit a 4. ábra foglalja, illetve hasonlítja össze a $[2,3,4,5]$ alapján.

\begin{tabular}{|c|c|c|}
\hline Az IWE & AzIWT & \multirow{12}{*}{$\begin{array}{c}\text { Az IWP } \\
\text { képzés célja ipari gyakorlattal } \\
\text { és hegesztöi képesitéssel } \\
\text { rendelkezó személyekböl } \\
\text { kvalifikáltabb gyakorlati } \\
\text { hegesztószakemberek képzése, } \\
\text { akik alkalmasak felügyelni és } \\
\text { irányítani hegesztök munkáját, } \\
\text { segíteni képesek gyártói } \\
\text { alkalmassággal rendelkezó } \\
\text { hegesztó üzemek hegesztési } \\
\text { felelösének munkáját, tudnak } \\
\text { ellátni szakmai feladatokat az } \\
\text { oktatásban és a } \\
\text { kereskedelemben is. } \\
\text { A gyakorlati képzésnek } \\
\text { személyes gyakorláson kell } \\
\text { alapulnia úgy, hogy a } \\
\text { résztvevök mélyítsék az } \\
\text { ismereteiket és gyakorlatukat } \\
\text { az általuk választott fó } \\
\text { hegesztési eljárással } \\
\text { kapcsolatosan. }\end{array}$} \\
\hline \multicolumn{2}{|c|}{$\begin{array}{l}\text { képzésben résztvevök kellö felkészültséget szerezzenek ahhoz, hogy képesek legyenek az } \\
\text { Irányelvben foglalt, }\end{array}$} & \\
\hline $\begin{array}{c}\text { a hegesztömérnöki } \\
\text { gyakorlatban }\end{array}$ & a hegesztési felelösi gyakorlatban & \\
\hline \multicolumn{2}{|c|}{\begin{tabular}{|l|l|} 
lényeges & \\
\end{tabular}} & \\
\hline \multicolumn{2}{|c|}{ hegesztési technológiák alkalmazására, ill. olyan } & \\
\hline átfogó és részletes & \begin{tabular}{|c|c|} 
általános & alap \\
\end{tabular} & \\
\hline \multicolumn{2}{|c|}{ szakismeretekkel rendelkezzenek, amelyek elegendók az üzemszerú hegesztési gyártás } & \\
\hline teljes körü & egyszerũ & \\
\hline \multirow{2}{*}{\multicolumn{2}{|c|}{$\begin{array}{c}\text { tervezéséhez, kivitelezéséhez, felügyeletéhez, ellenörzéséhez és irányításához. } \\
\text { A gyakorlati képzés célja, hogy a leendö }\end{array}$}} & \\
\hline & & \\
\hline 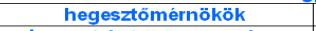 & \begin{tabular}{|l|l|} 
hegesztôtechnológusok & heges:ztöspecialisták \\
\end{tabular} & \\
\hline $\begin{array}{c}\text { ismereteket szerezzenek a } \\
\text { különbözó hegesztö eljárások } \\
\text { alkalmazásának ellenörzéséröl, } \\
\text { ill. ismerkedjenek meg - } \\
\text { amennyire csak lehetséges - az } \\
\text { egyes heglesztó eljárásokkal, az } \\
\text { eljárások nehézségeivel és a } \\
\text { nem megfelelö alkalmazás } \\
\text { során létrejövö eltérésekkel, } \\
\text { hibákkal. }\end{array}$ & $\begin{array}{l}\text { a gyakorlás és a bemutatók során alapvetó jártasságot } \\
\text { szerezzenek a fontosabbömlesztó és sajtoló eljárásokkal, } \\
\text { megismerjék a hegesztó berendezések müködését, kezelését, a } \\
\text { hegesztési technológiák alkalmazását, a leggyakrabban } \\
\text { elófor duló eltérés eket, híbákat és azok elkerülését, ill. javítását. }\end{array}$ & \\
\hline
\end{tabular}

4. ábra. A nemzetközi hegesztő szakember képzések föbb követelményei

\section{A képzések vizsgái}

A képzés első részének (1R) teljesítése után írásbeli tesztvizsgát kell tenni (2. ábra). Nemzetközi diplomát eredményező záróvizsgára az bocsátható, aki részt vett az ANB által jóváhagyott képzés tanóraszámának legalább 90\%-án és befizette a vizsgadíjat. Annak érdekében, hogy a kibocsátott diplomák egyenértéküek legyenek, nemcsak a képzésnek kell megfelelnie az IIW Irányelvének [1], hanem a vizsgát is az ANB felügyelete mellett kell lefolytatni.

A 4 tantárgyi modul szerint zajló vizsga célja annak megítélése, hogy a jelölt alkalmas-e tudásának és ismereteinek alkalmazására az ipari gyakorlatban, a képzési szintjén megoldandó feladatokban. A képzést lezáró vizsga részei:

- modulonként 20...30 (képzéstől függő számú) kérdésből - kérdésenként 4 válaszlehetőséggel - álló EWF on-line (elektronikus, internetes) tesztvizsga;

- modulonként 45..60 (3...4 válaszlehetőségü) kérdésből álló írásbeli tesztvizsga;
- modulonként 2 húzott tétel ismertetéséből álló szóbeli vizsga.

A sikeres vizsgát követően a nemzetközi és európai diplomá(ka)t az ANB bocsátja ki a jelöltnek, mely(ek)hez személyes IIW és EWF bélyegző (pecsét) is igényelhető. Az ezeken megjelenített információk: az IIW vagy az EWF felirat, a keresztnév kezdőbetüje ponttal + a családi név, a nemzeti ANB rövidítése, a diploma szintjének rövidítése, egyedi sorozatszám a vonatkozó diploma szerint, a diploma teljes megnevezése.

\section{Szakirodalmi hivatkozások}

[1] IIW Guideline for International Welding Engineers, Technologists, Specialists and Practitioners: IAB-252r2-14, EWF-IAB/IIW Secretariat, Porto Salvo, Feb. 2014, p. 111

[2] Információs lap a Nemzetközi hegesztőmérnök (IWE) képzésről, MHtE, 2015, 6 oldal

[3] Információs lap a Nemzetközi hegesztötechnológus (IWT) képzésröl, MHtE, 2015, 6 o.

[4] Információs lap a Nemzetközi hegesztőspec. (IWS) szakképzésröl, MHtE, 2015, 7 o.

[5] Információs lap a Nemzetközi kiemelt hegesztő (IWP) képzésről, MHtE, 2015, 6 o. 